\title{
\begin{tabular}{l|l|l} 
Jurnal Eksplorasi Akuntansi (JEA) & e-ISSN : 2656-3649 (Online) \\
Vol. 3, No 3, Agustus 2021, Hal 672-686 & http://jea.ppj.unp.ac.id/index.php/jea/index
\end{tabular}
}

\section{Faktor - Faktor Yang Mempengaruhi Kesiapan Aparatur Desa dalam Implementasi Pengelolaan Keuangan Dana Desa pada Masa Pandemi Covid-19}

\author{
Wahyu Ramadhan ${ }^{1 *}$, Fefri Indra Arza ${ }^{2}$ \\ 1,2 Fakultas Ekonomi, Universitas Negeri Padang \\ *Korespondensi: wahyuramdn12@gmail.com
}

\begin{abstract}
This study aims to determine the effect of communication, human resource competence, resistance to change and leadership commitment to the readiness of the apparatus in managing village funds during the pandemic. The population of this research is all Nagari apparatus in XX Koto District. The sample used is 72 respondents with total sampling technique. This study uses quantitative methods by distributing questionnaires directly. This study was tested using multiple regression analysis. The results obtained from this study indicate that communication and resistance to change have no significant effect on the readiness of village officials in managing village funds during the pandemic, while human resource competence and leadership commitment have a significant positive effect on the readiness of village officials in managing village funds during the pandemic.
\end{abstract}

Keywords: Apparatus Readiness; Communication; Human Resources Competence; Resistance to Change; Leadership Commitment.

How to cite (APA ${ }^{\text {th }}$ style)

Ramadhan, Wahyu \& Arza, F.I. (2021). Faktor - Faktor Yang Mempengaruhi Kesiapan Aparatur Desa Dalam Implementasi Pengelolaan Keuangan Dana Desa Pada Masa Pandemi Covid-19. Jurnal Eksplorasi Akuntansi. 3(3). 672-686.

\section{PENDAHULUAN}

Dampak penyebaran virus Covid-19 di Indonesia menuntut pemerintah serta masyarakat untuk mampu beradaptasi dengan cepat sesuai dengan perubahan kondisi yang ada, hal ini memaksa pemerintah untuk melakukan perubahan pada postur anggaran dan perubahan arah kebijakan pemerintah. Dengan keluarnya Perpu No.1/2020 tentang Kebijakan Keuangan Negara dan Stabilitas Sistem Keuangan untuk Penanganan Pandemi Corona Virus Disease 2019 (COVID-19) dan/atau dalam Rangka Menghadapi Ancaman yang Membahayakan Perekonomian Nasional dan/atau Stabilitas Sistem Keuangan maka pemerintah saat ini akan lebih berfokus kepada kegiatan penanganan Covid-19.

Terjadinya perubahan postur anggaran tidak hanya terjadi pada APBN dan APBD namun juga berubah pada postur anggaran APBDes. Perangkat desa merupakan bagian dari pemerintah yang bersentuhan secara langsung dengan masyarakat bawah harus mempersiapkan diri atas perubahan serta melakukan penyesuaian pada postur APBDes. penggunaan APBDes diatur melalui Permendesa PDTT Nomor 6 Tahun 2020 yang difokuskan pada pengeluaran-pengeluaran yang bersifat urgent untuk mencegah penyebaran 
serta penanganan Covid-19, sehingga merubah struktur belanja yang telah dianggarkan oleh pemerintah pada tahun sebelumnya.

Pengelolaan dana desa pada masa pandemi berbeda pada tahun-tahun sebelumnya yang mana penggunaan anggaran pada masa pandemi difokuskan kepada penanggulangan Covid-19. Salah satunya dengan dibentuknya program seperti Program Tanggap Darurat Covid-19 dengan anggaran yang dialokasikan dari dana Penanggulangan Bencana Darurat dan Pengeluaran Tak Terduga untuk kegiatan Penanggulangan Darurat. Kegiatan yang dilakukan berupa hal-hal untuk pencegahan virus Covid-19 dengan melakukan pengadaan bahan dan peralatan seperti semprotan, masker, Alat Pelindung Diri (APD) dan berbagai peralatan lainnya. Selanjutnya program bantuan yang diberikan oleh pemerintah desa berupa Bantuan Langsung Tunai (BLT). Total anggaran BLT dari Dana Desa sebesar Rp 600.000 per rumah tangga dalam waktu 3 bulan. Program BLT diberikan kepada masyarakat yang hanya memenuhi kriteria sebagai penerima.

Pada tahun-tahun sebelumnya anggaran untuk dana desa difokuskan kepada peningkatan kualitas sumber daya masyarakat, meningkatkan sarana prasarana dan juga meningkatkan kesejahteraan masyarakat serta meningkatkan infrastruktur desa. Namun rencana tersebut tidak bisa diterapkan dikarenakan pemerintah telah mengeluarkan peraturan Permendes No. 6 Tahun 2020 yang lebih memprioritaskan penggunaan anggaran dana desa untuk penanggulangan dampak Covid-19. Terbitnya peraturan baru ini pada pertengahan tahun membuat aparatur desa harus menyusun kembali rencana, anggaran serta kegiatan yang akan dilakukan untuk mencegah dampak dari pandemi Covid-19. Dengan sedikitnya waktu dalam menyusun perencanaan mengakibatkan aparatur desa menjadi kewalahan.

Selanjutnya dalam pelaksanaan kegiatannya seperti Dalam program Bantuan Langsung Tunai (BLT) yang akan diberikan kepada masyarakat desa, banyak hasil survei yang menyebabkan tidak tepat sasaran atas bantuan yang diberikan. Banyak orang mengeluh karena merasa penyaluran bantuan tidak adil dan tidak merata. Perubahan situasi anggaran yang mendesak dan sulitnya pelaksanaan di lapangan membuat penyiapan badan pengelola anggaran selama wabah ini menjadi fokus perhatian banyak pihak. Oleh karena itu, kesiapan perangkat pengelolaan dana desa di masa pandemi menjadi hal yang menarik.

Penelitian terdahulu telah menguji faktor-faktor yang mempengaruhi kesiapan implementasi peraturan pemerintah diantaranya Herlina (2013) dengan variabel keterampilan, variabel informasi dan variabel perilaku. Selanjutnya Arif (2015) dengan variabel komunikasi resistensi pada perubahan dan komitmen pimpinan. Pada Sari (2017) juga meneliti kesiapan aparatur dalam implementasi peraturan baru dengan variabel kompetensi SDM, gaya kepemimpinan dan struktur birokrasi. Sedangkan Iznillah (2015) juga meneliti variabel yang mempengaruhi kesiapan implementasi peraturan pemerintah yaitu komunikasi, kompetensi sumber daya manusia, komitmen organisasi dan komunikasi. Kesiapan aparatur dalam implementasi peraturan baru berperan penting dalam keberhasilan dari kinerja. Apabila kesiapan dari aparatur dalam melaksanakan implementasi pertauran baru tidak berjalan dengan baik maka hasil dari kinerja aparatur tentu juga akan terganggu.

\section{REVIU LITERATUR DAN HIPOTESIS \\ Teori Kesiapan}

Dalam suatu organisasi, perubahan harus selalu dilakukan untuk memperbaharui dan meningkatkan kualitas organisasi. Selain itu, perubahan harus dilakukan untuk beradaptasi dengan lingkungan eksternal untuk menjaga kelangsungan organisasi, karena itu semua anggota harus berperan untuk mencapai tujuan organisasi. Dalam melihat tingkat keberhasilan yang akan dicapai dalam tujuan organisasi, penting untuk mengetahui terlebih dahulu tingkat persiapan yang telah disiapkan. Kesiapan pekerja merupakan bagian penting dalam mendukung kesuksusan organisasi. Armenakis dkk mengemukakan dalam Arif (2015) 
kesiapan adalah penandaan konigtif terhadap perilaku dari penolakan atau dukungan terhadap upaya perubahan. Dan siap untuk berubah adalah ketika orang-orang dan struktur organisasi sudah dipersiapkan serta mampu untuk berubah.

Menurut Holt et al dalam Arif (2015), kesiapan untuk berubah didefinisikan sebagai sikap komprehensif yang mempengaruhi secara berkelanjutan dari isi (yaitu, apa yang sedang berubah), proses (yaitu, bagaimana perubahan di laksanakan), konteks (yaitu, keadaan dimana perubahan itu terjadi) dan individu (yaitu, karakteristik dari mereka yang diminta untuk berubah) yang terlibat. Selain itu, keadaan kesiapan kolektif menggambarkan sejauh mana satu atau lebih individu cenderung secarakognitif dan emosional untuk menerima, merangkul, dan mengaplikasikan rencana khusus yang ditujukan untuk mencapai kesuksesan.

Jadi berdasarkan pendapat di atas dapat disimpulkan kesiapan mengahadapi perubahan akan menunjang keberhasilan suatu organisasi dalam melakukan implementasi peraturan, semakin siap organisasi maka peluang keberhasilan dalam melakukan perubahan atas implementasi peraturan baru semakin besar. Dalam penelitan ini peneliti menggunakan variabel komunikasi, resistensi ada perubahan, kompetensi sumber daya manusia dan komitmen pimpinan untuk melihat pengaruhnya terhadap kesiapan aparatur dalam implementasi pengelolaan dana desa dimasa pandemi

\section{Pemerintah desa}

Menurut Permendesa No.6 (Pasal 1 Ayat 1) pada Bab 1 Tahun 2020, desa adalah desa dan desa adat, atau disingkat desa, kesatuan masyarakat hukum yang berhak mengurus dan mengatur urusan pemerintahan, kepentingan masyarakat lokal didasarkan pada prakarsa republik, prakarsa masyarakat yang dihormati dan diakui dalam sistem pemerintahan, hak masyarakat adat dan/ atau hak tradisional Indonesia.

Pemerintahan desa merupakan sub sistem dari sistem pemerintahan nasional. Ada pasal yang mengatur tentang pembentukan pemerintah desa dan perangkat desa, pasal ini akan menjadikan kepala desa sebagai pimpinan pemerintahan desa, dan BPD juga akan membatasi peran kepala desa atau organisasi perwakilan lainnya yang bersifat keaslian lokal.

\section{Pengelolaan Keuangan Dana Desa}

Menurut Peraturan Nomor 6 Bab 1 Tahun 2020 (Pasal 1 ayat 1), dana perdesaan adalah dana yang digunakan untuk penyelenggaraan pemerintahan, penyelenggaraan pembangunan, pemberdayaan masyarakat, dan pelaksanaan kewenangan masyarakat yang dialokasikan dari anggaran pendapatan dan belanja negara yang disalurkan melalui anggaran pendapatan dan belanja daerah/ perkotaan. Pemerintah menetapkan anggaran dana desa nasional dalam APBN setiap tahun yang diperoleh dari pengeluaran pemerintah dengan cara mengefektifkan perencanaan berbasis desa secara berkeadilan dan merata.

\section{Kesiapan Implementasi Permendesa No.6 Tahun 2020}

Covid-19 mempengaruhi perekonomian Indonesia seperti fungsi anggaran pada pemerintahan karena berdampak terhadap kontraksi penerimaan, seperti berkurangnya kemampuan masyarakat dalam berkonsumsi dan menabung akan berakibat kepada berkurangnya potensi investasi dan keuntungan (Herlina, 2020). Hal tersebut mengakibatkan terjadinya pengurangan anggaran terhadap APBN hingga pada dana desa, untuk menanggulangi hal tersebut pemerintah telah menerbitkan berbagai kebijakan, termasuk kebijakan dalam Permendesa No.6 Tahun 2020 tentang prioritas dana desa.

Untuk dapat menghadapi babak baru dalam penerapan Permendesa No.6 Tahun 2020 tentang prioritas penggunaan dana desa. Dalam hal ini pemerintahan desa harus mempersiapkan terkait kesiapan serta perencanaan mendapatkan pencapaian yang maksimal dalam pelaksanaannya. Dengan demikian pemerintah desa harus memperhatikan berbagai 
faktor yang mempengaruhi kesiapan dalam implementasi permendesa nomor 6 tahun 2020 agar mencapai tujuan keberhasilan.

\section{Hubungan Komunikasi Dengan Kesiapan Aparatur Desa Dalam Implementasi Pengelolaan Keuangan Dana Desa Pada Masa Pandemi Covid-19}

Menurut Edward dalam Herlina (2013), dalam proses implementasi dipengaruhi oleh beberapa variabel, veriabel komunikasi merupakan salah satunya. Komunikasi kebijakan yang efektif berarti bahwa pengguna kebijakan mengetahui dengan jelas apa yang mereka lakukan, yang meliputi konsistensnya sebuah informasi, kejelasannya sebuah informasi, dan proses penyampaian sebuah informasi yang dikomunikasikan. Komunikasi berarti mengkomunikasikan ide/gagasan dengan menetapkan titik temu sama terlebih dahulu. Syarat utama komunikasi kebijakan yang efektif adalah pelaksana kebijakan harus mengenal serta memahami apa yang mereka lakukan, yang mencakup dalam proses penyampaian sebuahinformasi dan konsistennya sebuah informasi yang disampaikan.

Menurut Arif (2015) fakotr komunikasi berpengaruh signifikan terhadap implementasi peraturan pemerintah. Selanjutnya menurut Iznillah (2015) variabel komunikasi berpengaruh terhadap imlementasi kesiapan aparatur pemerintah. Berdasarkan hal di atas dapat dirumuskan hipotsis :

H1: Komunikasi berpengaruh signifikan positif terhadap kesiapan aparatur desa dalam implementasi pengelolaan keuangan dana desa pada masa pendemi Covid-19

\section{Hubungan Kompetensi Sumber Daya Manusia dengan Kesiapan Aparatur Desa dalam Implementasi Pengelolaan Keuangan Dana Desa Pada Masa Pandemi Covid-19}

Kompetensi sumber daya manusia memiliki posisi yang sangat penting untuk menyukseskan implementasi peraturan pemerintah. Hal ini juga disebutkan oleh Sari (2017) penelitiannya menunjukkan komptensi sumber daya manusia berpengaruh terhadap kesiapan aparatur pemerintah dalam implementasi peraturan pemerintah. Menurut Wibowo dalam penelitian Putri (2017) Kemampuan sumberdaya manusia adalah kemampuan yang berkaitan dengan pengetahuan, keterampilan, kemampuan dan karakteristik kepribadian yang secara langsung mempengaruhi kinerjanya.

Menurut Putri (2017) kompetensi sumber daya mausia berpengaruh signifikan terhadap kesiapan aparatur dalam implementasi peraturan daerah. Selunjut hal tersebut juga didukung oleh Iznillah (2015) yang mengatakan sumber daya manusia berpengaruh terhadap kesiapan dalam implementasi peraturan pemerintah. Berdasarkan hal di atas dapat dirumuskan hipotesis :

H2: Kompetensi Sumber Daya Manusia berpengaruh signifikan positif terhadap kesiapan aparatur desa dalam implementasi pengelolaan keuangan dana desa pada masa pendemi Covid-19

\section{Hubungan Resistensi pada Perubahan dengan Kesiapan Aparatur Desa dalam Implementasi Pengelolaan Keuangan Dana Desa Pada Masa Pandemi Covid-19}

Menurut Arif (2015), faktor resistensi terhadap perubahan berhubungan dengan kecondongan parapekerja untuk tidak mau mengikuti perubahan sejalan dengan perubahan organisasi, baik itu individu maupun keseluruhan. Sementara itu, menurut penelitian Boohoene dan Williams (Lumintang et al., 2021), resistensi dianggap sebagai masalah yang menggagu kinerja dalam organisasi karena pegawai cendrung menghindari perubahan dan mengganggu keberhasilan implementasi perubahan peraturan. Ketika perubahan diperkenalkan dalam suatu organisasi, maka timbul sebuah kecemasan yang mnimbulkan keraguan bagi parapekerja. Menurut Arif (2015) fakotr resistensi pada perubahan berpengaruh 
secara signifikan terhadap implementasi peraturan pemerintah. Berdasarkan hal tersebut maka hipotesa yang dibangun adalah:

H3: Resistensi pada perubahan berpengaruh signifikan positif terhadap kesiapan aparatur desa dalam implementasi pengelolaan keuangan dana desa pada masa pendemi Covid-19

\section{Hubungan Komitmen Pimpinan dengan Kesiapan Aparatur Desa dalam Implementasi Pengelolaan Keuangan Dana Desa Pada Masa Pandemi Covid-19}

Faktor komitmen kepemimpinan yang berkaitan dengan sikap atau perilaku anggota organisasi biasanya dipengaruhi oleh sisem budaya yang dianut dalam organisasi, serta dari pemimpin. Komitmen yang tidak memadai berarti bahwa pemimpin kurang memiliki rasa tanggung jawab dalam menjalankan tugasnya. Mempertanyakan komitmen sama dengan mempertanyakan tanggung jawab, oleh karena itu dalam hal ini ukuran komitmen pemimpin terkait dengan implementasi kebijakan.

Jika pimpinan suatu instansi pemerintah memiliki keterampilan manajemen yang luas dan pengalaman teknis dalam mengelola instansi pemerintah, maka komitmen persiapan dapat terpenuhi. Hal ini memungkinkan organisasi untuk merumuskan dan menerapkan kebijakan yang mendorong standar kompetensi untuk setiap posisi dan fungsi di lembaga pemerintah. Mempertahankan dan meningkatkan kapasitas SDM, pimpinan hendaknya mempuanyi keyakinan, motivasi serta melaksanakan diskusi pembimbingan secara berkelanjutan. Selanjutnya menurut Arif (2015) faktor Komitmen Pimpinan berpengaruh secara parsial terhadap implementasi peraturan pemerintah. Berdasarkan hal di atas dapat dirmuskan hipotsesis :

H4: Komitmen Pimpinan berpengaruh signifikan positif terhadap kesiapan aparatur desa dalam implementasi pengelolaan keuangan dana desa pada masa pendemi Covid-19

\section{METODE PENELITIAN}

\section{Jenis dan Objek Penelitian}

Penelitian ini merupakan penelitian kausatif. Penelitian kausatif adalah tipe penelitian dengan karakteristik masalah penelitian berupa sebab akibat antara dua variabel (Sugiyono,2012). Dalam penelitian ini peneliti ingin melihat bagaimana pengaruh komunikasi, kompetensi sumber daya manusia, resistensi pada perubahan dan komitmen pimpinan terhadap kesiapan aparatur desa dalam implementasi pengelolaan dana desa pada masa pandemi Covid-19.

\section{Populasi dan sampel}

Populasi dalam penelitian ini adalah aparatur nagari yang bertugas di nagari yang ada di kecamatan Sepuluh Koto. Hal ini dikarenakan aparatur nagari merupakan orang-orang yang berkewajiban sebagai pengelolaa dana desa di nagari sehingga dinilai telah memahami pengelolaan atas dana desa. Populasi pada penelitian ini sejumlah 108 orang. Sampel dalam penelitian ini adalah pegawai aparatur nagari yang ada di kecamatan Sepuluh Koto kabupaten. Tanah Datar propinsi Sumatera Barat. Teknik pengambilan pada penelitian ini menggunakan teknik total sampling. Sampel pada penelitian ini berjumlah 108 orang.

\section{Teknik Pengumpulan Data}

Teknik yang digunakan dalam pengumpulan data menggunakan teknik survei melalui penyebaran kuesioner. Dalam melaksanakan metode ini, peneliti akan terjun langsung guna mendapatkan data yang diperlukan karena metode ini memerlukan kontak antara peneliti dengan responden. Penyebaran kuesioner yang difokuskan kepada aparatur desa pada Kecamatan Sepuluh Koto kabupaten. Tanah Datar propinsi Sumatera Barat 


\section{Variabel penelitian}

\section{Komunikasi}

Faktor komunikasi terkait dengan kebijakan pemerintah terkait pencegahan Covid-19. Fungsi komunikasi suatu program hanya dapat dilaksanakan dengan benar hanya jika informasi jelas bagi pelaksananya. Ini melibatkan proses transmisi informasi, kejelasan informasi, dan konsistensi informasi.

\section{Kompetensi Sumber Daya Manusia}

Kompetensi sumber daya manusia berhubungan dengan implementasi kebijakan sumberdaya manusia sebagai pelaksana organisasi. Menurut Wibowo dalam Arif (2015) berpendapat bahwa kapabilitas sumber daya manusia berkaitan dengan Pengetahuan, kemampuan, keterampilan dan karakteristik kepribadian secara langsung mempengaruhi kinerja mereka.

\section{Resistensi pada Perubahan}

Resistensi terhadap perubahan berkaitan dengan keengganan pekerja untuk mengikuti tren perubahan organisasi, baik individu maupun organisasi.

\section{Komitmen Pimpinan}

Komitmen kepemimpinan berkaitan dengan sistem nilai maupun budaya organisasi yang dianut oleh pimpinan organisasi yang mempengaruhi sikap atau perilaku anggota organisasi.

\section{Pengukuran variabel}

Pengukuran variabel komunikasi, kompetensi sumber daya manusia, resistensi pada perubahan dan komitmen pimpinan menggunakan skala likert dengan lima alternatid jawaban dan masing-masing akan diberikan skor yaitu: nilai 1= Sangat Tidak Setuju (STS), 2= Tidak Setuju (TS), 3= Kurang Setuju (KS), 4= Setuju (S) dan 5= Sangat Setuju (SS).

\section{HASIL DAN PEMBAHASAN}

\section{Gambaran Umum Objek Penelitian}

Populasi pada penelitian ini adalah seluruh nagari yang yang berada di kecamatan Sepuluh Koto, yaitu dengan jumlah 9 nagari. Sampel dalam penelitian ini adalah seluruh perangkat nagari, sehingga jumlah kuesioner yang disebar dalam penelitian ini sebanyak 72 kuesioner. Penyebaran kuesioner dilakukan secara langsung, dari 72 kuesioner yang disebar yang kembali sebanyak 72 kuesioner. Kuesioner dibagikan pada tanggal 9 Juli 2021 hingga 11 Juli 2021. Pengambilan kuesioner dilakukan juga secara langsung mulai tanggal 14 Juli 2021 hingga 15 Juli 2021. Berikut adalah gambaran penyebaran dan pengembalian kuesioner dalam penelitian ini:

\section{Tabel 1}

Penyebaran dan Pengembalian Kuesioner

\begin{tabular}{lc}
\hline \multicolumn{1}{c}{ Keterangan } & Jumlah Responden \\
\hline Jumlah kuesioner yang disebar & 72 \\
Jumlah kuesioner yang kembali & 72 \\
Respon rate & $100 \%$ \\
\hline
\end{tabular}

Sumber: Data primer yang sudah diolah

\section{Uji Normalitas}

Uji Normalitas bertujuan untuk menguji apakah model regresi variabel penganggu atau residual memiliki distribusi normal atau tidak ((Ghozali, 2012). Uji normalitas dalam penelitian ini yaitu dengan uji statistik Kolmogorov Smirnov Test dengan tingkat signifikasi 
pada 0,005 atau 5\%. Apabila nilai signifikasi $>0,05$ maka data berdistrubusi normal, sedangkan jika nilai signifikasi yang dihasilkan $<0,05$ maka data tidak berdistribusi normal. Hasil uji normalitas pada penelitian ini dapat dilihat pada tabel di bawah ini:

Tabel 2

Hasil Uji Normalitas

One-Sample Kolmogorov-Smirnov Test

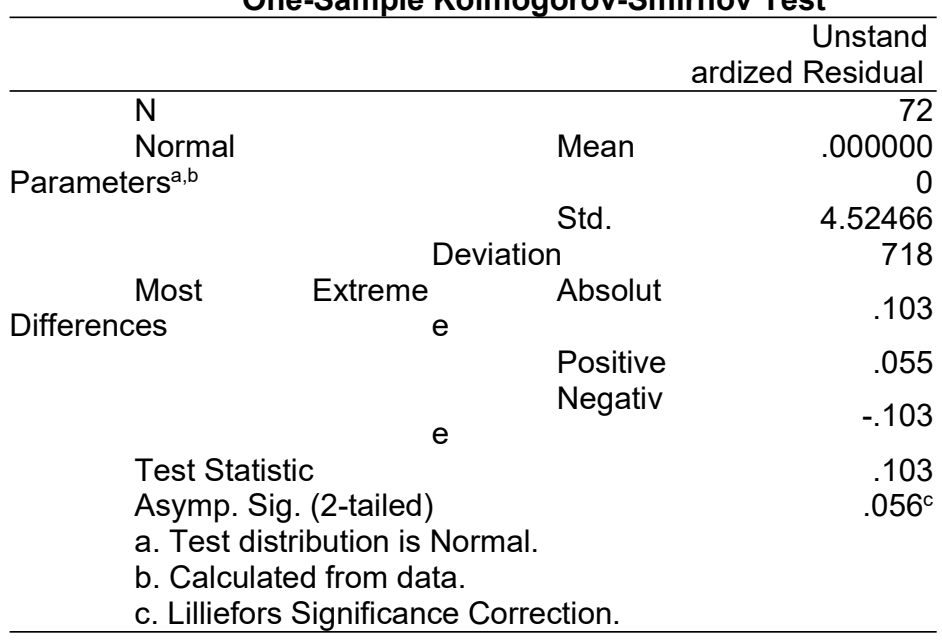

Berdasarkan hasil uji normalitas di atas terlihat bahwa hasil uji normalitas menunjukkan level signifikasi lebih besar dari $\alpha(\alpha=0,05)$ yaitu $0,056>0,05$ yang berarti bahwa data terdistribusi secara normal.

\section{Uji Multikolinieritas}

Uji Multikolinieritas bertujuan untuk menguji apakah model regresi ditemukan adanya korelasi antar variabel bebas (independen) (Ghozali, 2012). Model regresi yang baik seharusnya tidak terjadi korelasi diantara variabel bebas (independen). Untuk mendeteksi adanya multikolinieritas dapat dilihat dari nilai tolerance dan variance inflation factor (VIF). Nilai cutoff yang biasa dipakai untuk menunjukkan adanya multikolonieritas adalah nilai tolorance $<0,10$ dan nilai $V I F>10$. Jika nilai tolorance $>0,10$ dan nilai $V I F<10$ maka tidak terjadi multikolinearitas. Hasil uji multikolinieritas pada penelitian ini dapat dilihat pada Tabel di bawah ini:

Tabel 3

Hasil Uji Multikolinieritas

\begin{tabular}{|c|c|c|c|}
\hline & & \multicolumn{2}{|c|}{ Collinearity Statistics } \\
\hline \multicolumn{2}{|c|}{ Model } & Tolerance & VIF \\
\hline \multirow[t]{5}{*}{1} & (Constant) & & \\
\hline & Komunikasi & .622 & 1.609 \\
\hline & Komepetnsi_Sumber_Daya_Manusia & .584 & 1.711 \\
\hline & Resistensi_Pada_Perubahan & .798 & 1.253 \\
\hline & Komitmen_Pimpinan & .743 & 1.346 \\
\hline \multicolumn{4}{|c|}{ a. Dependent variabel: $Y$} \\
\hline
\end{tabular}

Berdasarkan tabel di atas, dapat diketahui setiap variabel pada penelitian memiliki nilai VIF $<10$ dan nilai tolerane $>0.1$ sehingga dapat disimpulkan tidak terjadi gejala multikolinearitas pada data penelitian. 


\section{Uji Heterokedastisitas}

Uji Heterokedastisitas bertujuan untuk menguji apakah dalam model regresi terjadi ketidaksamaan variance dari residual satu pengamatan ke pengamatan yang lain (Ghozali, 2012). Model regresi yang baik adalah tidak terjadi heterokedastisitas.Dalam mendeteksi adanya heterokedastisitas dapat diuji dengan uji Glejser. Dalam uji Glejser apabila hasilnya sig $>0,05$ berarti tidak mengalami heterokedastisitas, sedangkan apabila sig $<0,05$ berarti mengalami heteroskedastisitas. Hasil uji heterokedastisitas pada penelitian ini dapat dilihat pada Tabel 4 di bawah ini:

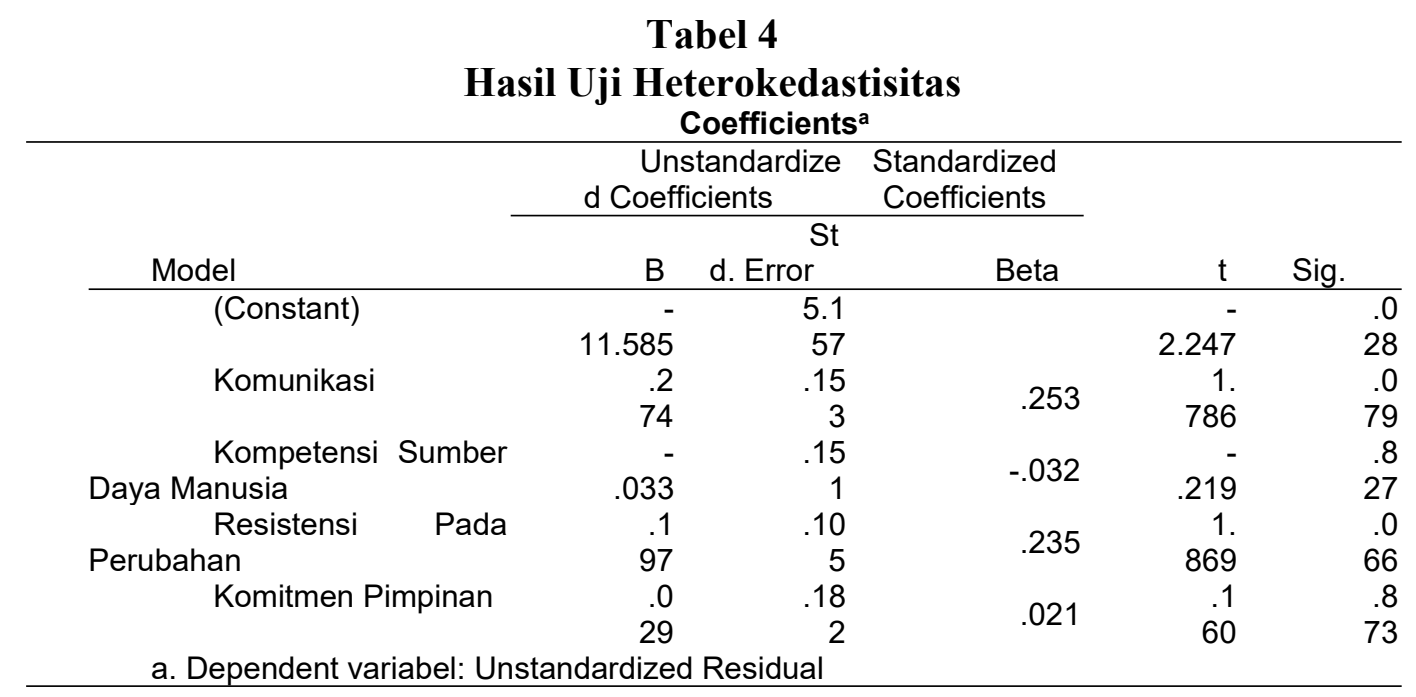

Berdasarkan Tabel di atas, dapat diketahui setiap variabel pada penelitian memilikinilai signifikansi pada variabel independen $>0,05$. Sehingga dapat disimpulkan data penelitian tidak mengalami heterokedastisitas.

\section{Analisis Regresi Berganda}

Analisis regresi linear berganda digunakan dalam penelitian ini dengan tujuan untuk mengetahui ada tidaknya pengaruh variabel bebas terhadap variabel terikat. Ringkasan hasil pengolahan data dengan menggunakanprogram SPSS 22 adalah sebagai berikut:

\section{Tabel 5}

\section{Hasil Analisis Regresi Berganda}

Coefficients $^{\mathrm{a}}$

\begin{tabular}{|c|c|c|c|c|c|c|}
\hline \multirow{2}{*}{\multicolumn{2}{|c|}{ Model }} & \multicolumn{2}{|c|}{ Unstandardized Coefficients } & \multirow{2}{*}{$\begin{array}{c}\begin{array}{c}\text { Standardized } \\
\text { Coefficients }\end{array} \\
\text { Beta } \\
\end{array}$} & \multirow[b]{2}{*}{$t$} & \multirow[b]{2}{*}{ Sig. } \\
\hline & & B & Std. Error & & & \\
\hline 1 & (Constant) & 12.431 & 7.587 & & 1.638 & .106 \\
\hline & Komunikasi & -.193 & .226 & $.110^{-}$ & -.854 & .396 \\
\hline & Kompetensi & & & & & \\
\hline & $\begin{array}{l}\text { Sumber } \\
\text { Daya } \\
\text { Manusia } \\
\text { Resistensi }\end{array}$ & .697 & .222 & .416 & 3.141 & .003 \\
\hline & $\begin{array}{l}\text { Pada } \\
\text { Perubahan }\end{array}$ & -.021 & .155 & $.016^{-}$ & -.137 & .891 \\
\hline & $\begin{array}{l}\text { Komitmen } \\
\text { Pimpinan }\end{array}$ & .665 & .268 & .294 & 2.478 & .016 \\
\hline
\end{tabular}

a. Dependent variabel: Kesiapan Aparatur 
Berdasarkan Tabel di atas, persamaan regresi yang telah dirumuskan dengan program SPSS 22 dilakukan pengolahan data sehingga didapat persamaan sebagai berikut:

$$
Y=12.431-0.193 X 1+0.697 X 2-0.021 X 3+0.665 X 4+7.587
$$

Nilai konstanta yang tercantum sebesar 12.431 dapat jika variabel komunikasi, kompetensi sumber daya manusia, resistensi pada perubahan dan komitmen dianggap konstan (0), maka pemanfaatan laporan keuangan pemerintah daerah adalah sebesar 12.431 satuan. Koefisien regresi variabel komunikasi $\left(\mathbf{b}_{1}\right)$ bernilai negatif sebesar -0.193 . Hal ini menujukkan bahwa jika komunikasi mengalami peningkatan sebesar satu satuan,maka akan menaikkan Kesiapan aparatur sebesar -0.193 satuan. Koefisien regresi variabel kompetensi sumber daya manusia $\left(\mathbf{b}_{2}\right)$ bernilai positif sebesar 0.697. Hal ini menujukkan bahwa jika kompetensi sumber daya manusia mengalami peningkatan sebesar satu satuan,maka akan menaikkan kesiapan aparatur sebesar 0.697 satuan. Koefisien regresi variabel resistensi pada perubahan ( $\mathbf{b}_{3}$ ) bernilai negatif sebesar -0.021. Hal ini menunjukkan bahwa jika resistensi pada perubahan mengalami peningkatan sebesar satu satuan, maka akan menurunkan kesiapan aparatur sebesar -0.021 satuan. Koefisien regresi variabel komitmen pimpinan ( $\left.\mathbf{b}_{4}\right)$ bernilai positif sebesar 0.665 . Hal ini menujukkan bahwa jika komitmen pimpinan mengalami peningkatan sebesar satu satuan, maka akan menaikkan kesiapan aparatur sebesar 0.665 satuan. Error $=\mathbf{7 . 5 8 7}$ Error yang terdapat dalam persamaan regresi di atas menunjukkan adanya resiko kesalahan, ini bermakna sedikit atau banyak keputusan dalam penolakan atau penerimaan hipotesis mengandung kemungkinan terjadi kesalahan.

\section{Uji Hipotesis}

Uji Koefisien Determinasi (R Square)

\section{Tabel 6 \\ Hasil Uji Determinasi $R$ Square}

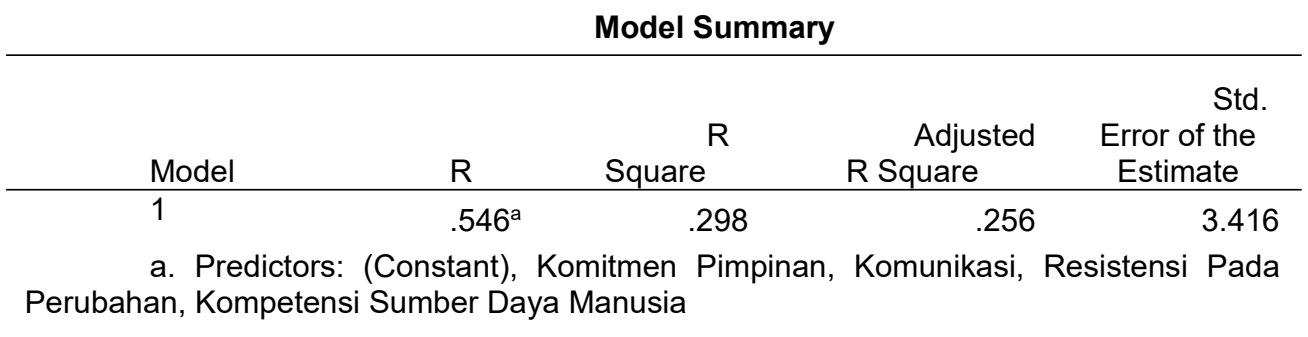

Sumber: Hasil pengolahan data SPSS 22

Berdasarkan tabel di atas, nilai Adjusted R-Square sebesar 0.298 atau 29.8\%. Hal ini menunjukkan bahwa besar pengaruh variabel independen (X1, X2, X3 dan X4) secara bersama-sama mempengaruhi variabel dependen (Y) sebesar $\mathbf{2 9 . 8 \%}$, sementara sisanya $70.2 \%$ dipengaruhi oleh variabel lain yang tidak di analisis dalam penelitian ini. 
Uji F (F-test)

Tabel 7

Hasil Uji F

ANOVA $^{\mathrm{a}}$

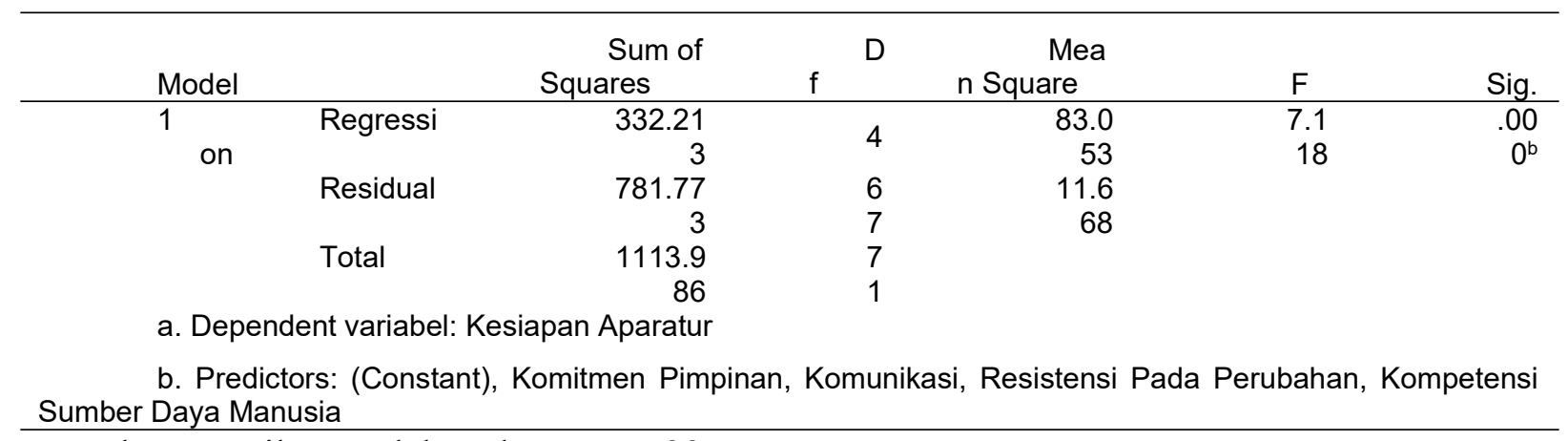

Sumber : Hasil pengolahan data SPSS 22

Berdasarkan Tabel di atas dapat diketahui nilai $\mathrm{F}_{\text {hitung }}$ sebesar $7.118>\mathrm{F}_{\text {tabel }}$ sebesar 2.51 dan nilai signifikan sebesar $0.000<0.05$. maka dapat disimpulkan bahwa komunikasi, kompetensi sumber daya manusia, resistensi pada perubahan dan komitmen pimpinan secara simultan memiliki pengaruh signifikan terhadap kesiapan aparatur dalam implementasi pengelolaan dana desa pada masa pandemi karena $F_{\text {hitung }}>F_{\text {tabel }}$ dan signifikansi $<0,05$.

\section{Uji Hipotesis (Uji T)}

Tabel 8

Hasil Uji T

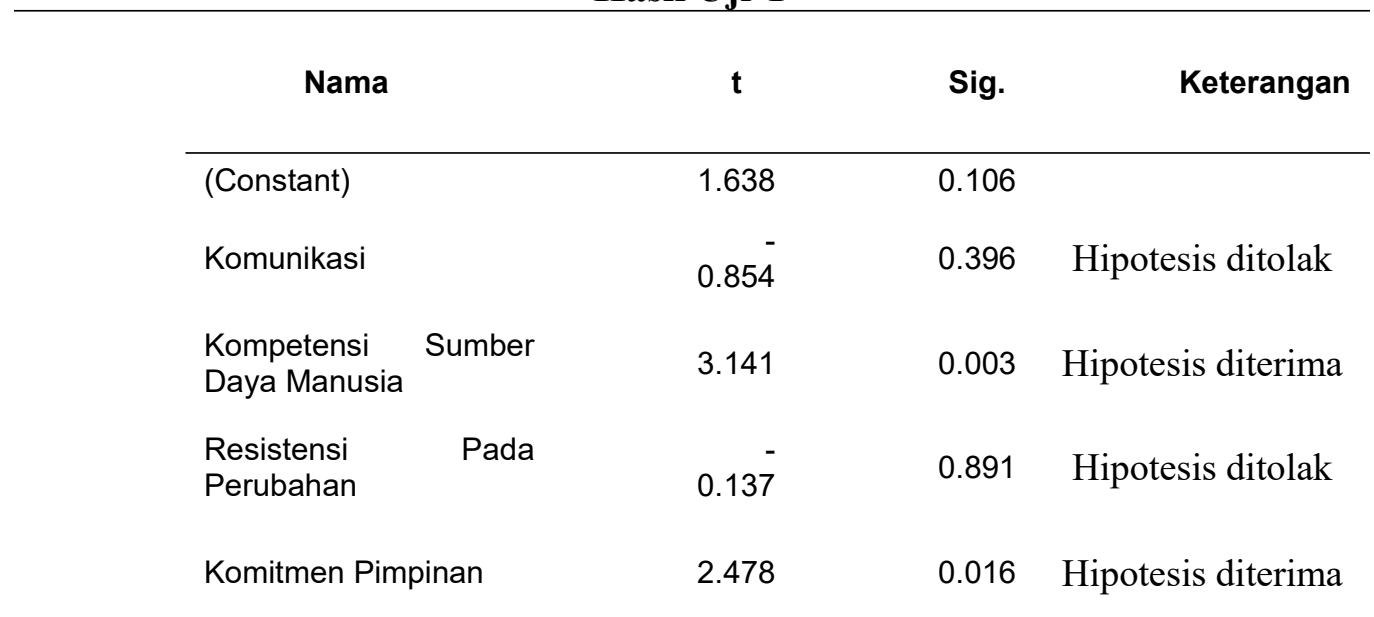

\section{Sumber: Hasil pengolahan data SPSS 22}

Hipotesis pertama menyatakan bahwa komunikasi berpengaruh negatif terhadap kesiapan aparatur dalam implementasi pengelolaan dana desa dimasa pandemi. Berdasarkan Tabel di atas, diketahui bahwa nilai thitung sebesar $-0.854<\mathrm{t}_{\text {tabel }}$ sebesar 1.9944 dengan nilai signifikansi sebesar $0.396>0.05$. Berdasarkan hasil uji t dapat disimpulkan bahwa hipotesis pertama yang menyatakan Komunikasi berpengaruh positif terhadap kesiapan aparatur dalam implementasi pengelolaan dana desa dimasa pandemi, ditolak.

Hipotesis kedua menyatakan bahwa kompetensi sumber daya manusia berpengaruh positif terhadap kesiapan aparatur dalam implementasi pengelolaan dana desa dimasa pandemi. Berdasarkan Tabel di atas, diketahui bahwa nilai thitung sebesar $3.141>t_{\text {tabel }}$ sebesar 
1.9944 dengan nilai signifikansi sebesar $0.003<0.05$. Berdasarkan hasil uji $t$ dapat disimpulkan bahwa hipotesis kedua yang menyatakan bahwa kompetensi sumber daya manusia berpengaruh positif terhadap kesiapan aparatur dalam implementasi pengelolaan dana desa dimasa pandemi, diterima.

Hipotesis ketiga menyatakan bahwa resistensi pada perubahan berpengaruh positif terhadap kesiapan aparatur dalam implementasi pengelolaan dana desa dimasa pandemi. Berdasarkan Tabel di atas, diketahui nilai $t_{\text {hitung }}$ sebesar $-0.137<t_{\text {tabel }}$ sebesar 1.9944 dengan nilai signifikansi sebesar $0.891>0.05$. Berdasarkan hasil uji t dapat disimpulkan bahwa hipotesis ketiga yang menyatakan resistensi pada perubahan berpengaruh positif terhadap kesiapan aparatur dalam implementasi pengelolaan dana desa dimasa pandemi, ditolak.

Hipotesis keempat menyatakan bahwa komitmen pimpinan yang berpengaruh positif terhadap kesiapan aparatur dalam implementasi pengelolaan dana desa dimasa pandemi. Berdasarkan Tabel di atas, diketahui nilai thitung sebesar $2.478>t_{\text {tabel }}$ sebesar 1.9944 dengan nilai signifikansi sebesar $0.016<0.05$. Berdasarkan hasil uji t dapat disimpulkan bahwa hipotesis keempat yang menyatakan bahwa komitmen pimpinan berpengaruh positif terhadap kesiapan aparatur dalam implementasi pengelolaan dana desa dimasa pandemi, diterima.

\section{Pembahasan \\ Pengaruh Komunikasi terhadap Kesiapan Aparatur Dalam Implementasi Pengelolaan Dana Desa Pada Masa Pandemi}

Hipotesis pertama pada peneltian ini menyatakan bahwa komunikasi berpengaruh positif terhadap kesiapan aparatur dalam pengelolaan dana desa pada masa pandemi. Berdasarkan hasil uji t pada penelitian ini dimukan bahwa $\mathrm{H} 1$ ditolak karena thitung sebesar $0.854<t_{\text {tabel }}$ sebesar 1.9944 dengan signifikansi sebesar $0.396>0.05$. Artinya, komunikasi tidak berpengaruh terhadap kesiapan aparatur dalam pengelolaan dana desa pada masa pandemi. Dalam variabel komunikasi tidak berpengaruh terhadap variabel kesiapan aparatur dalam pengelolaan dana desa dimasa pandemi disebabkan karena komunikasi kebijakan efektif masih belum sepenuhnya diterapkan pada tingkat nagari hal ini juga disebabkan karna jumlah aparatur nagari yang tergolong sedikit berjumlah 8 orang..

Penelitian ini berbeda dengan penelitian terdahulu yang dilakukan oleh Sari (2017) yang hasil penelitiannya menyatakan bahwa komunikasi berpengaruh terhadap Kesiapan aparatur dalam pengelolaan dana desa pada masa pandemi. Selain itu penelitian ini juga berbeda dengan penelitian yang dilakukan oleh Ferdian F (2018) yang hasil penelitiannya juga mengatakan bahwa komunikasi berpengaruh terhadap kesiapan aparatur dalam implementasi.

\section{Pengaruh Kompetensi Sumber Daya Manusia terhadap Kesiapan Aparatur Dalam Implementasi Pengelolaan Dana Desa Pada Masa Pandemi}

Hipotesis kedua pada peneltian ini menyatakan bahwa kompetensi sumber daya manusia berpengaruh positif terhadap Kesiapan aparatur dalam pengelolaan dana desa pada masa pandemi. Berdasarkan hasil uji t pada penelitian ini dimukan bahwa $\mathrm{H} 2$ diterima karena $t_{\text {hitung }}$ sebesar $3.141>t_{\text {tabel }}$ sebesar 1.9944 dengan signifikansi sebesar $0.003<0.05$. Artinya, Kompetensi sumber daya manusia berpengaruh positif signifikan terhadap kesiapan aparatur dalam pengelolaan dana desa pada masa pandemi. Besaran peningkatan kompetensi sumber daya manusia berbanding lurus dengan besaran peningkatan Kesiapan aparatur dalam pengelolaan dana desa pada masa pandemi, semakin meningkat kompetensi sumber daya manusia, maka Kesiapan aparatur dalam pengelolaan dana desa pada masa pandemi akan semakin meningkat pula.

Temuan ini mengindikasikan bahwa kompetensi sumber daya manusia memiliki peranan penting dalam meningkatkan Kesiapan aparatur dalam pengelolaan dana desa pada 
masa pandemi. Hasil penelitian ini sejalan dengan penelitian Sari (2017) dan Putri (2017) yang menyatakan bahwa kompetensi sumber daya manusia berpengaruh signifikan terhadap kesiapan aparatur dalam implementasi peraturan daerah. Selain itu penelitian ini sejalan dengan hasil penelitian yang dilakukan oleh Iznillah (2015) yang mengatakan sumber daya manusia berpengaruh positif terhadap kesiapan dalam implementasi peraturan pemerintah.

\section{Pengaruh Resistensi Pada Parubahan terhadap Kesiapan Aparatur Dalam Implementasi Pengelolaan Dana Desa Pada Masa Pandemi}

Hipotesis ketiga pada penelitian ini menyatakan bahwa resistensi pada perubahan berpengaruh positif terhadap Kesiapan aparatur dalam pengelolaan dana desa pada masa pandemi. Berdasarkan hasil uji t pada penelitian ini dimukan bahwa $\mathrm{H} 3$ ditolak karena thitung sebesar $-0.137<t_{\text {tabel }}$ sebesar 1.9944 dengan signifikansi sebesar $0.891>0.05$. Artinya, resistensi pada perubahan tidak berpengaruh terhadap kesiapan aparatur dalam pengelolaan dana desa pada masa pandemi.

Hasil dalam pengujian hipotesis ini menunjukkan resistensi pada perubahan tidak memiki pengaruh terhadap kesiapan aparatur, hal ini menunjukkan bahwa aparatur nagari dalam menghadapi perubahan pengelolaan dana desa pada masa pandemi tidak memiliki keengganan dalam melakukan perubahan baik itu dalam anggaran maupun dalam kegiatan. Hasil penelitian ini berbeda dengan penelitan yang dilakukan oleh Arif (2015) yang menyatakan bahwa resistensi pada perubahan berpengaruh terhadap kesiapan aparatur. Selanjutnya Fitri A (2017) juga mengatakan bahwa resistensi pada perubahan berpengaruh terhadap implementasi peratiran baru.

\section{Pengaruh Komitmen Pimpinan terhadap Kesiapan Aparatur Dalam Implementasi Pengelolaan Dana Desa Pada Masa Pandemi}

Hipotesis keempat pada peneltiian ini menyatakan bahwa komitmen pimpinan berpengaruh positif terhadap Kesiapan aparatur dalam pengelolaan dana desa pada masa pandemi. Berdasarkan hasil uji t pada penelitian ini dimukan bahwa $\mathrm{H} 4$ diterima karena $t_{\text {hitung }}$ sebesar $7.481>\mathrm{t}_{\text {tabel }}$ sebesar 1.6546 dengan signifikansi sebesar $0.000<0.05$. Artinya, komitmen pimpinan berpengaruh positif signifikan terhadap kesiapan aparatur dalam pengelolaan dana desa pada masa pandemi. Besaran peningkatan komitmen pimpinan yang dimiliki penggunanya berbanding lurus dengan besaran peningkatan Kesiapan aparatur dalam pengelolaan dana desa pada masa pandemi, semakin meningkat komitmen pimpinan yang dimiliki aparatur, maka Kesiapan aparatur dalam pengelolaan dana desa pada masa pandemi akan semakin meningkat pula.

Dalam meningkatkan kesiapan aparatur dalam pengelolaan dana desa dimasa pandemi maka diperlukan komitmen dari pimpinan. Komitmen pimpinan akan menjadi faktor pendorong bagi aparatur dalam meningkatkan kesiapan. Kesiapan aparatur dibentuk berdasakan kepala desa, hal ini akan menjadi pendorong bagi aparatur untuk mengikuti komitmen dari pimpinan sehingga mengharuskan aparatur untuk memiliki kesiapan dalam mengimplementasikan pengelolaan dana desa dimasa pandemi, sedangkan apabila pimpinan tidak memiliki komitmen yang kuat dalam melaksanakan implementasi pengelolaan dana desa pada saat masa pandemi maka akan mengurangi keberhasilan dalam program-program yang direcanakan pada awal sebelum kegiatan. Penelitian ini didukung oleh penelitian terdahulu yang dilakukan oleh Arif (2015) yang menyatakan bahwa komitmen pimpinan berpengaruh terhadap kesiapan aparatur dalam implementasi peraturan baru, lalu pada penelitian Puspitarini (2017) juga mengatakan bahwa komitmen pimpinan berpengaruh positif terhadap implementasi peraturan baru. 


\section{SIMPULAN, KETERBATASAN DAN SARAN \\ Kesimpulan}

Berdasarkan hasil temuan penelitian dan pengujian hipotesis yang telah dilakukan dapat disimpulkan bahwa kompetensi sumber daya manusia dan komitmen pimpinan berpengaruh positif terhadap kesiapan aparatur dalam implementasi pengelolaan dana desa pada masa pandemi, selanjutnya variabel komunikasi dan resistensi pada perubahan tidak berpengaruh terhadap kesiapan aparatur dalam implementasi pengelolaan dana desa pada masa pandemi. Adapun hasil keempat variabel tersebut:

1. Komunikasi tidak berpengaruh terhadap kesiapan aparatur dalam implementasi pengelolaan dana desa pada masa pandemi. Hasil penelitian ini mengatakan bahwa aparatur nagari tidak mempermasalahkan komunikasi dalam melakukan persiapan dalam pengelolaan dana desa. Hal tersebut dikarenakan jumlah dari aparatur nagari yang hanya berjumlah 8 orang sehingga hubungan komunikasi pada nagari sudah berjalan dengan baik

2. Kompetensi sumber daya manusia berpengaruh positif dan signifikan terhadap kesiapan aparatur dalam implementasi pengelolaan dana desa dimasa pandemi. Hasil penelitian ini aparatur nagari sebagian besar telah melaksanakan pembekelan serta pelatihan untuk melakukan implementasi peraturan baru sehingga kesiapan aparatur dalam implementasi pengelolaan dana desa dimasa pandemi sudah cukup baik.

3. Resistensi pada perubahan tidak berpengaruh terhadap kesiapan aparatur dalam implememntasi pengelolaan dana desa dimasa pandemi. Hasil penelitian ini menunjukkan bahwa sikap monolak akan perubahan tidak dimiliki oleh aparatur nagari, dalam menghadapi perubahan aparatur nagari masih bisa melakukan persiapan dengan cukup baik dalam mengimplementasikan pengelolaan dana desa.

4. Komitmen pimpinan berpengaruh positif dan signifikan terhadap kesiapan aparatur dalam implementasi pengelolaan dana desa dimasa pandemi. Hasil penelitian ini pimpinan telah memiliki komitmen yang baik terhadap dana desa sehingga menimbulkan kesiapan terhadap implementasi pengelolaan dana desa dimasa pandemi.

\section{Keterbatasan}

Keterbatasan penelitian ini adalah penelitian ini merupakan metode survei menggunakan kuesioner. Data penelitian yang berasal dari responden yang disampaikan secara tertulis mungkin akan mempengaruhi hasil penelitian, karena persepsi responden yang disampaikan belum tentu mencerminkan keadaan yang sebenarnya dan akan berbeda apabila data diperoleh melalui wawancara.

\section{Saran Untuk Penelitian Selanjutnya}

Berdasarkan pembahasan dan kesimpulan di atas berupa variabel komunikasi, kompetensi sumber daya manusia, resistensi pada perubahan dan komitmen pimpinan, adapun saran peneliti untuk kedepannya adalah:

a) Metode penelitian selanjutnya dapat menggunakan metode wawancara untuk menguatkan bukti penelitin.

b) Menambahkan variabel lain dalam penelitian ini, seperti sarana prasarana dan komitmen pribadi.

c) Menambahkan pelatihan untuk staff nagari seperti pelaporan pengelolaan dana desa yang telah dilakukan atas pekerjaannya. 


\section{DAFTAR PUSTAKA}

Arif, W. (2015) Analisis Faktor-Faktor Yang Mempengaruhi Kesiapan Pemerintah Kota Tanjungpinang Dalam Implementasi Peraturan Pemerintah Nomor 71 Tahun 2010 Tentang Standar Akuntansi Pemerintah.

Fitri, A. (2017). Pengaruh Kompetensi Sumber Daya Manusia, Resistensi Terhadap Perubahan dan Sistem Informasi terhadap Implementasi Standar Akuntansi Pemerintahan Berbasis Akrual (Studi Empiris pada SKPD Pemerintahan Kota Pariaman). Jurnal Akuntansi, 5(2).

Ferdian, F. (2018). Analisis Faktor Faktor Yang Mempengaruhi Penerapan Akuntansi Basis Akrual Pada Pemerintahan Di Kota Padang (Studi Empiris Organisasi Perangkat Daerah Kota Padang). Jurnal Akuntansi, 6(3).

Ghozali, Imam. 2012 "Aplikasi Analisis Multivariate dengan Program IBM SPSS”, 20 Edisi Keenam, Semarang: Universitas Diponegoro.

Handayani, D., Hadi, D. R., Isbaniah, F., Burhan, E., \& Agustin, H. (2020). Corona Virus Disease 2019. Jurnal Respirologi Indonesia, 40(2), 119-129.

Hanoatubun, S. (2020). Dampak Covid-19 terhadap Prekonomian Indonesia. EduPsyCouns: Journal of Education, Psychology and Counseling, 2(1), 146-153.

Herlina, H. (2013). Analisis Faktor-Faktor Yang Mempengaruhi Kesiapan Pemerintahan Daerah Dalam Implementasi PP 71 Tahun 2010 (Studi Empiris: Kabupaten Nias Selatan). Jurnal Akuntansi, 1(3).

Herlina, H. (2020). Perubahan Fluktuatif Struktur Ekonomi Indonesia Pada Masa Pandemi Covid-19. Al-Mutharahah: Jurnal Penelitian Dan Kajian Sosial Keagamaan, 17(2), 199-210.

Lumbantoruan, C. M., Tewal, B., \& Lumintang, G. (2021). Faktor-faktor yang menyebabkan resistensi terhadap perubahan organisasi di pt. Pertamina (persero) integrated terminal bitung. Jurnal EMBA: Jurnal Riset Ekonomi, Manajemen, Bisnis dan Akuntansi, 9(1).

Musianto, L. S. (2004). Perbedaan pendekatan kuantitatif dengan pendekatan kualitatif dalam metode penelitian. Jurnal Manajemen dan kewirausahaan, 4(2), pp-123.

Putri, D. U. (2017, July). Pengaruh Kompetensi Sumber Daya Manusia, Komitmen Organisasi Dan Fungsi Komunikasi Terhadap Penerapan Standar Akuntansi Pemerintahan Berbasis Akrual Pada Satuan Kerja Perangkat Daerah Di Kota Bandung. Seminar Nasional Akuntansi dan Bisnis (SNAB), Fakultas Ekonomi Universitas Widyatama.

Puspitarini, I., Firmansyah, A., \& Handayani, D. (2017). Pengaruh Kompetensi Sumber Daya Manusia dan Komitmen Pimpinan Terhadap Penerapan Akuntansi Berbasis Akrual Pada Pengelolaan Barang Milik Negara. Profesionalisme Akuntan Menuju Sustainable Business Practice, 540-549.

Sari, R. P. (2017). Pengaruh Komunikasi, Kompetensi Sumberdaya Manusia, Struktur Birokrasi, Dan Gaya Kepemimpinan Terhadap Implementasi Standar Akuntansi Pemerintah Basis Akrual (Studi Empiris Pada Pemerintah Daerah Kota Bukittinggi). Jurnal Akuntansi, 5(2).

Silfi, A., Azlina, N., \& Iznillah, M. L. (2015). Pengaruh Kualitas Sumber Daya Manusia, Komitmen Organisasi, Teknologi Informasi, dan Komunikasi terhadap Kesiapan Pemerintah dalam Menerapkan Standar Akuntansi Pemerintah Berbasis Akrual (Studi Empiris pada Pemerintah Kabupaten Indragiri Hilir) (Doctoral dissertation, Riau University). 
Sugiyono, 2012, Metodelogi Penelitian Kuantitatif, Kualitatif Dan R\&D. (Bandung: ALFABETA)

Yuliana, Y. (2020). Corona virus diseases (Covid-19): Sebuah tinjauan literatur. Wellness And Healthy Magazine, 2(1), 187-192.

Zahrotunnimah, Z. (2020). Langkah taktis pemerintah daerah dalam pencegahan penyebaran virus Corona Covid-19 di Indonesia. SALAM: Jurnal Sosial Dan Budaya Syar-I, 7(3), 247-260. 